\title{
Alveolar Macrophages in Influenza A Infection Guarding the Castle with Sleeping Dragons
}

\author{
Lindsay Somerville ${ }^{1,2 *}$, Amber Cardani ${ }^{2,3}$ and Thomas J. Braciale ${ }^{2,3,4}$ \\ ${ }^{1}$ Pulmonary and Critical Care Medicine, University of Virginia Health System, Charlottesville, Virginia, United States of America \\ ${ }^{2}$ Beirne B. Carter Center for Immunology Research, University of Virginia, Charlottesville, Virginia, United States of America \\ ${ }^{3}$ Department of Microbiology, University of Virginia, Charlottesville, Virginia, United States of America. \\ ${ }^{4}$ Department of Pathology, University of Virginia, Charlottesville, Virginia, United States of America
}

${ }^{\star}$ Corresponding author: Lindsay Somerville, Pulmonary and Critical Care Medicine, University of Virginia Health System, Charlottesville, Virginia, United States of America

Received: March 27, 2020; Accepted: April 04, 2020; Published: May 15, 2020

\section{Influenza $A$ is a Worldwide Burden and Recurring Threat}

Despite major advances in influenza vaccination and flu-prevention community awareness campaigns, Influenza A virus (IAV) remains a worldwide and recurring threat $[1,2]$. Seasonal influenza causes 3-5 million cases of severe respiratory and systemic illness and upwards of 650,000 deaths annually, particularly among the elderly, very young, and chronically ill [3]. Countless hours of missed school and work have significant economic consequences $[4,5]$. In pandemic years, morbidity and mortality soars, especially among the young $[6,7]$.

\section{The Influenza A Viral Infection Cycle}

In humans, influenza A targets epithelial cells of the respiratory tract via droplet inhalation. Viral Hemagglutinin (HA) protein binds to sialic acid receptors decorating the surface of polarized respiratory epithelial host cells. If the patient has repeated exposure to the same IAV strain, or one with similar HA antigenic structure, IAV-specific IgG and secretory IgA antibodies may neutralize and thereforeeliminate the virus.Circulating CD4+ helper T-cells directed against influenza proteins may hasten the effectors $\mathrm{T}$ cell response; as well as provide some direct antiviral function by targeted destruction of infected cells, limiting viral spread $[8,9]$. Antigen-specific effector $\mathrm{CD} 8+\mathrm{T}$ cells primed against internal viral antigens, when present, clear virus and destroy infected cells, thus limiting severity of disease $[9,10]$. If the virus is not cleared by these mechanisms, or if the host response is impaired (as with smokers and other conditions), retrograde infection can proceed from the upper respiratory tract to the lower.Following virion uptake in the cell endosome and uncoating viral RNA is transported to the host cell nucleus, where the virus begins replication and transcription, utilizing host cell mRNA capstealing mechanisms to induce viral mRNA synthesis [11]. New viral RNAs are transcribed and viral proteins translated, and new virions are assembled in the infected host cell $[12,13]$. This cellular hijacking turns the host into a virus-manufacturing machine, shutting down host cell protein synthesis while simultaneously inhibiting infectioninduced apoptosis [14, 15]. Viral nucleic acids and proteins are, are transported to the cell surface, packaged into new virionswhich bud off the plasma membrane and released via the action of viral neuraminidase (NA) enzyme. Virions can retain host cell membrane sialic acid receptors for the HA,enabling virions to clump. These large viral clusters may spread more easily through the lower respiratory tract; NA cleaves these domains, allowing virions to disperse in the distal airway $[13,16]$.

\section{Alveolar Macrophages: The Primary Defensive Line and Cleanup Crew of the Lower Respiratory Tract}

Lung macrophages derive from multiple lineages, and play different roles in the lung. Alveolar macrophages (AMФ), thought to derive fromprogenitors present in fetal liver [17] move to the lung interstitium during development then migrate to the air-tissue interface after birth, where they maintain and repopulate locally through life. AM $\Phi$ are tightly adherent to alveolar epithelial cells. This cell-cell contact plays a key role in homeostasis and function. Under the direction of GM-CSF, these macrophages primarily remove surfactant and cellular debris, preventing Pulmonary Alveolar Proteinosis (PAP). They are also responsible for phagocytosis of foreign pathogens that have overcome or bypassed the mechanical defenses and immune defenses of the upper airway [18]. АM $\Phi$ regenerate locally, as demonstrated by longterm persistence of donor macrophages in patients who undergo lung transplant $[19,20]$. If there is complete loss of alveolar macrophages, as in irradiation, АM $\Phi$ will regenerate from circulating monocytes [21].

By contrast, interstitial pulmonary macrophages, which make up a smaller proportion of lung macrophages derive from bone marrow precursors, and play a different role in lung immune defense: namely antigen-presentation and modulation of tissue injury [22]. A third, smaller subset of primitive macrophages, derives from yolk sac progenitors, and resides in the mesothelium adjacent to the vasculature $[19,23]$. АМФ play myriad roles in the lungs, including localized homeostasis, injury repair and remodeling, and innate defense. Perhaps their most remarkable feature is the capacity toselectively regulate induction of the adaptive immune response to foreign 
pathogenswhich invade the terminal airways at the air-tissue interface [24]. Under homeostatic conditions AMФ, like microglia, primarily exist in a resting state controlled by interaction between the OX-2 membrane glycoprotein CD200 and the CD200 receptor through TGF $\beta$ signaling [25]. In this state, AMФ downregulate expression of macrophage $\mathrm{CD} 11 \mathrm{~b}$, a surfaceintegrin protein critical for phagocytosis $[24,26]$, thus phagocytic activity is suppressed. AM $\Phi$ adhere tightly to alveolar type I and type II cells. In this quiescent state macrophages induce low localized levels of av $\beta 6$ integrinin alveolar epithelial cells, which binds to the latency associated peptide (LAP) of TGF $\beta$ to form latent-TGF $\beta$ on AMФ [27]. This complex suppresses AMФproduction of proinflammatory and cellular recruiting cytokines interleukin 1beta (IL-1 $\beta$ ), tumor necrosis factor-alpha (TNF- $\alpha$ ), interleukin-6 (IL-6) and interleukin-8 (IL-8) [28].Suppression of phagocytosis and inhibition of inflammatory cytokine release regulates activation of the adaptive immune response and mitigates unchecked inflammation and edema that might otherwise impair alveolar gas exchange [29].

Alveolar macrophages become activated when AMФ pattern recognition receptors (PRRs) interact with pathogen-associated molecular patterns (PAMPs) in the respiratory tract [30]. Activation induces conformational changes resulting in loss of contact with alveolar epithelial cells. Interruption of cellular contact abruptly halts av $\beta 6$ integrin binding with LAP binding and results in loss of latent-TGF $\beta$. Without latent-TGF $\beta$ production, the suppression of $\mathrm{AM} \Phi$ phagocytic activity and cytokine production is lost, priming AM $\Phi$ to produce TNF- $\alpha$ and IL-6, becoming cell-recruitmentand phagocytic machines [31]. Activated macrophages recruit neutrophils and inflammatory monocytes to the airways (and interstitium) which replace resident alveolar macrophages over the course of several days [32,33]. Once activated, these macrophages have astonishing phagocytic and pro-inflammatory activity. MacLean and Kradin's in vivo rat model demonstrated that $10^{9}$ intratracheally-injectedListeria organisms before macrophage spillover occurs [34]. Fine particulate activation of AMФ induces high levels of reactive oxygen species (ROS), 8-isoprostane, and Arachidonic Acid (AA) metabolites including prostaglandin $\mathrm{E}_{2}\left(\mathrm{PGE}_{2}\right)$, leukotriene $\mathrm{B}_{4}\left(\mathrm{LTB}_{4}\right)$ [35]. Within days of insult, $\mathrm{T}$ lymphocytes and natural killer cells are recruited to the site of injury, where they secrete interferon gamma (IFN- $\gamma$ ) [36]. IFN- $\gamma$ stimulates matrix metalloproteinase (MMP-9) production by $\mathrm{AM}$, which alternatively activates latentTGF $\beta$ on macrophages. This induces macrophages to re-adhere to epithelium, restoring suppression of inflammation and phagocytosis, and returning $\mathrm{AM} \Phi$ to their homeostatic inflammation-suppressing state [24].

\section{The Alveolar Macrophage Arsenal against Influenza A}

AMФ employ several pattern recognition receptors against influenza. The primary pathogen-associated molecular patterns generated by influenza A are cytoplasmic viral RNAs produced during cellular viral replication $[37,38]$ and viral M2 protein.AMФ exposed to IAV have marked upregulation of type I interferons (especially $\alpha 1$, $4,7,8,13,17$, and 21), chemokine CXC motif ligands 5, 9, 10, and 11; fibroblast activation protein $\alpha$ (FAP);TNF- $\alpha$, and members of the IL-1 family [39]. As AMФ endocytose virions, viral membrane degradation releases viral ssRNA into the macrophage cytoplasm. Viral ssRNA is recognized as foreign by AMФ toll-like receptor 7 (TLR7), inducing the NF- $\mathrm{KB}$ inflammatory signaling pathway expression. AM $\Phi$ phagocytose dying IAV-infected alveolar epithelial cells and cellular debris. As cells are degraded, viral dsRNA is recognized by TLR3 [40],further inducing NF- $\mathrm{kB}$ inflammatory signaling, and producing type I interferons (IFN-I) $[38,41]$, and inducing expression of monocyte-recruiting chemokines like CCL2 [42]. In Infected AMФviral RNA released in cytoplasm is recognized by retinoic acidinducible gene I (RIG-I), which activates mitochondrial antiviral signaling protein (MAVS) [43]. The viral matrix ion channel protein M2 induces formation of the NOD-LRR-pyrin domain-containing inflammasome 3 (NLRP3), activating caspases, and releasing IL-1 $\beta$ [44].

\section{Alveolar Macrophages Play a Unique Role in the Protection Against Influenza A Infection}

Cardani and Braciale et al(2017) demonstrated that AMФ are critical in the protection of type I alveolar epithelial cells (AEC-I) against lethal influenza infection [45].The authors developed a novel mouse model in which there is a cellular deficiency of mature alveolar macrophages. AMФ-deficient mice infected with sublethal doses of intranasal IAV developed acute respiratory distress syndrome and death 8-12 days post-infection. In these mice, IAV spreads unchecked throughout the lower respiratory tract, resulting in massive inflammation upon effector T-cell elimination of infected cells. They further demonstrated that intranasal administration of $А М \Phi$ up to 24 hours post-infection rescued these mice from lethal infection by limiting IAV spread, illustrating the time-dependent role of AMФ in IAV respiratory infection. The authors determined that АMФ suppress autocrine production of cysteinyl leukotriene D4 in AEC-I, and that protection against IAV by $\mathrm{AM} \Phi$ could be replicated with drugs targeting the same downstream metabolites of the arachidonic acid pathway inhibiting production of cysteinyl leukotrienes. These finding demonstrated a previously unappreciated, protective role of AMФ in Influenza A infection.

\section{References}

1. Thompson WW, Moore MR, Weintraub E, Weintraub E, Cheng PY(2009)et al. Estimating influenza-associated deaths in the United States. Am J Pub Health 99:225230. [crossref]

2. Morbidity and Mortality Weekly Report (MMWR). (n.d.). Retrieved from https:// www.cdc.gov/mmwr/preview/mmwrhtml/mm5933al.htm

3. Influenza (Seasonal). (n.d.). Retrieved from

4. https://www.who.int/en/news-room/fact-sheets/detail/influenza-(seasonal)

5. Thompson WW, Shay DK, Weintraub E, Brammer L, Cox N et al. (2003) Mortality associated with influenza and respiratory syncytial virus in the United States. JAMA 289:179-186. [crossref]

6. Thompson WW, Shay DK, Weintraub E, Brammer L, Bridges CB et al. (2004) Influenza-associated hospitalizations in the United States. JAMA 292:1333-1340.

7. Comparing deaths from pandemic and seasonal influenza. (2015, June 21). Retrieved from https://www.who.int/csr/disease/swineflu/notes/briefing_20091222/en/

8. Shrestha SS, Swerdlow DL, Borse RH, Prabhu VS, Finelli LEstimating the burden of 2009 pandemic influenza A (H1N1) in the United States (April 2009-April 2010). Clin Infect Dis1: 75-82. [crossref] 
9. Wilkinson TM, Li CK, Chui CS, Huang AK Y, Perkins M et al. (2012). Preexisting influenza-specific CD4 T cells correlate with disease protection against influenza challenge in humans. Nature Medicine18: 274-80. [crossref]

10. Pizzolla A, Wakim LM (2019) Memory T Cell Dynamics in the Lung during Influenza Virus Infection. The Journal of Immunology 20: 374-381. [crossref]

11. Wang, $\mathrm{Z}$ et al.(2015) Recovery from severe H7N9 disease is associated with diverse response mechanisms dominated by CD8+ T cells. Nat Commun. 6:6833.

12. Martín-Benito J, Ortín J (2013) Influenza Virus Transcription and Replication. Advances in Virus Research 87: 113-137. [crossref]

13. Treanor JJ. (2005) In: Principles and Practice of Infectious Disease. Influenza virus 2060

14. Rello J, Pop-Vicas A (2009) Clinical review: Primary influenza viral pneumonia. Critical Care 13: 235. [crossref]

15. Bender BS, Small PA Jr (1992) Influenza: pathogenesis and host defense. Semin Respir Infect 7:38-45. [crossref]

16. Zhirnov OP, Klenk HD (2007) Control of apoptosis in influenza virus-infected cells by up-regulation of Akt and p53 signaling. Apoptosis12: 1419-1432. [crossref]

17. Stiver G. (2003). The treatment of influenza with antiviral drugs. CMAJ168: 49-57. [crossref]

18. Guilliams M, Kleer ID, Henri S, Post S, Vanhoutte L (2013) Alveolar macrophages develop from fetal monocytes that differentiate into long-lived cells in the first week of life via GM-CSF. The Journal of Experimental Medicine210: 1977-1992. [crossref]

19. Epelman S, Lavine KJ, Randolph GJ (2014) Origin and Functions of Tissue Macrophages. Immunity41: 21-35. [crossref]

20. Tan SY, Krasnow MA (2016) Developmental origin of lung macrophage diversity. Development 143: 1318-1327. [crossref]

21. Eguíluz-Gracia I, Schultz HHL, Sikkeland LIB, Danilova E, Holm AM et al. (2016) Long-term persistence of human donor alveolar macrophages in lung transplant recipients. Thorax71: 1006-1011.[crossref]

22. Sibille Y, Reynolds HY (1990) Macrophages and Polymorphonuclear Neutrophils in Lung Defense and Injury. American Review of Respiratory Disease 141: 471-501. [crossref]

23. Schneberger D, Aharonson-Raz K, Singh B (2010) Monocyte and macrophage heterogeneity and Toll-like receptors in the lung. Cell and Tissue Research 343: $97-$ 106. [crossref]

24. Takahashi K, Yamamura F, Naito M (1989) Differentiation, Maturation, and Proliferation of Macrophages in the Mouse Yolk Sac: A Light-Microscopic, EnzymeCytochemical, Immunohistochemical, and Ultrastructural Study. Journal of Leukocyte Biology 45: 87-96. [crossref]

25. Lambrecht BN (2006) Alveolar Macrophage in the Drivers Seat. Immunity 24: 366368. [crossref]

26. Varol C, Mildner A, Jun S (2015) Macrophages: Development and Tissue Specialization. Annual Review of Immunology 33: 643-675. [crossref]

27. Fossati-Jimack L, Ling GS, Cortini A, Szajna M, Malik TH et al. (2013) Phagocytosis Is the Main CR3-Mediated Function Affected by the Lupus-Associated Variant of CD11b in Human Myeloid Cells. PLoS One 8(2). [crossref]

28. Katsumoto TR, Violette SM, Sheppard D (2011) Blocking TGF $\beta$ via Inhibition of theav 36 Integrin: A Possible Therapy for Systemic Sclerosis Interstitial Lung Disease. International Journal of Rheumatology1-7.
29. García JE, Rodríguez FM, Cabo MR, Salgado MJ, Losada JP et al. (1999) Evaluation of Inflammatory Cytokine Secretion by Human Alveolar Macrophages. Mediators of Inflammation, 8: 43-51.[crossref]

30. Holt PG (1978). Inhibitory Activity of Unstimulated Alveolar Macrophages on T-Lymphocyte Blastogenic Response1. American Review of Respiratory Disease118: 791-793. [crossref]

31. Ding X, Jin S, Tong Y, Jiang X, Chen Z (2017) TLR4 signaling induces TLR3 upregulation in alveolar macrophages during acute lung injury. Scientific Reports 7: 34278. [crossref]

32. Persoons JH, Schornagel K, Tilders FF, Vente JD, Berkenbosch F (1996) Alveolar macrophages autoregulate IL-1 and IL- 6 production by endogenous nitric oxide. American Journal of Respiratory Cell and Molecular Biology 14: 272-278.[crossref]

33. Maus UA, Janzen S, Wall G, Srivastava M, Blackwell TS et al. (2006) Resident Alveolar Macrophages Are Replaced by Recruited Monocytes in Response to EndotoxinInduced Lung Inflammation. American Journal of Respiratory Cell and Molecular Biology, 35: 227-235. [crossref]

34. Rubins JB (2003) Alveolar Macrophages. American Journal of Respiratory and Critical Care Medicine167: 103-104.

35. MacLean JA, Xia W, Pinto CE, Zhao L, Liu HW et al. (1996) Sequestration of inhaled particulate antigens by lung phagocytes: a mechanism for the effective inhibition of pulmonary cell- mediated immunity. Am J Pathol148:657-666. [crossref]

36. Beck-Speier I, Dayal N, Karg E, Maier KL, Schumann G (2005) Oxidative stress and lipid mediators induced in alveolar macrophages by ultrafine particles. Free Radical Biology and Medicine38: 1080-1092.[crossref]

37. Fenton MJ, Vermeulen MW, Kim S, Burdick M, Strieter RM (1997) Induction of gamma interferon production in human alveolar macrophages by Mycobacterium tuberculosis. Infection and Immunity 65: 5149-5156. [crossref]

38. Hale BG, Albrecht RA, García-Sastre A (2010) Innate immune evasion strategies of influenza viruses. Future Microbiology 5: 23-41. [crossref]

39. Iwasaki A, Pillai PS (2014) Innate immunity to influenza virus infection. Nature Reviews Immunology14: 315-328. [crossref]

40. Wang J, Nikrad MP, Travanty EA, Zhou B, Phang T (2012) Innate Immune Response of Human Alveolar Macrophages during Influenza A Infection. PLoS ONE 7: 29879. [crossref]

41. Zhang J, Miao J, Hou J, Lu C (2015) The effects of H3N2 swine influenza virus infection on TLRs and RLRs signaling pathways in porcine alveolar macrophages. Virology Journal 12: 61. [crossref]

42. Xu Y, Liu L (2017) Curcumin alleviates macrophage activation and lung inflammation induced by influenza virus infection through inhibiting the NF- $\mathrm{KB}$ signaling pathway. Influenza and Other Respiratory Viruses 11: 457-463. [crossref]

43. Saelens X (2019) The Role of Matrix Protein 2 Ectodomain in the Development of Universal Influenza Vaccines. The Journal of Infectious Diseases219: 68-74.[crossref]

44. Wang R, Zhu Y, Lin X, Ren C, Zhao J (2019) Influenza M2 protein regulates MAVSmediated signaling pathway through interacting with MAVS and increasing ROS production. Autophagy 15: 1163-1181. [crossref]

45. Ichinohe T, Pang IK, Iwasaki A (2010) Influenza virus activates inflammasomes via its intracellular M2 ion channel. Nature Immunology 11: 404-410.

46. Cardani A, Boulton A, Kim TS, Braciale TJ (2017) Alveolar Macrophages Prevent Lethal Influenza Pneumonia By Inhibiting Infection Of Type-1 Alveolar Epithelial Cells. PLOS Pathogens 13. [crossref] 